\title{
Reflexions about the Neo-classicist Dispositions of a Prohibited Playwright
}

\author{
Dr. Besa Shingjergji \\ Faculty of Human Sciences, Department of Albanian Language and Literature, UE “A. Xhuvani”. Elbasan, Albania \\ Email address: besashingjergji@gmail.com
}

\section{Doi:10.5901/ajis.2016.v5n3s1p57}

\section{Abstract}

The literary work of the Albanian playwright Etëhem Haxhiademi had been prohibited, due to vengeful political principles, for more than four decades. . He was one of the most notable creators of the Albanian tragedy divulging in the modern period of the Albanian literature. In 1924 he wrote the tragedy "Ulysses" in Berlin, in 1926 he wrote the tragedy "Achilles" in Vienna and in 1928 he wrote the tragedy "Alexander" in Lushnje, Albania. The three tragedies were published in Tirana, Albania, in 1931. Later on he writes and publishes the tragedy "Pyrrhus" (1934), "Scanderbeg" "Skënderbeu" (1935), "Diomedes" (1936) and "Abeles" (1938). He was also known as the creator of the poetical volume "Lyra", (1939), His dramatic work has been set up in accordance with models of classical tragedy, making use of the antiquity or medieval subjects, even stretching back to Biblical pre-history. His literary work becomes functional to revelations which can be compared with phenomena, ideas and the problems featuring the reality of the time he wrote his works. By striving to make the notions of classicism clearer in this writing, we have directly contributed to the estimation of the literary work of E. Haxhiademi which, in our opinion, has excessive concomitances in ideas, aesthetic ideals and practices conceiving the neo-classicism experiences in Europe.

Keywords: Prohibited playwright, tragedy, classical canon, neo-classicist dispositions.

\section{Introduction}

Before presenting our point of view related to the neoclassic inclinations of our dramatic author, we thought it over to provide some insights related to the effects the neoclassic drama models had in his tragedies.

Etehem Haxhiademi created seven tragedies, mainly in the first half of the 20th century (1920s and 1930s), with their subjects taken from the Albanian antiquity and Middle Ages, ("Pyrrhus", "Alexander", "Scanderbeg"), from ancient mythology ("Achilles", "Diomedes", "Ulysses"), as well as from biblical subjects ("Abel") by so abiding to the fundamental tendency of the classical playwrights.

Haxhiademi's persistent endeavour to return to classical tragedy, while the prosperity of this literary genre had already vanished in the period he wrote, can be explained with the efforts to give a new push to dramaturgy - one of the less developed genres in the Albanian literature. Because of its conventionality in the Albanian literature, this genre could advance solely on paths that had already been trampled by others. It could not be evolved differently but by applying models which had been considered by the European literature as instances of its perfection.

Certainly, the return of the Albanian genre of classical drama to the models of classical tragedy was not weird but, in general terms, it created a sort of anachronism in the background of the general evolvement inclinations in the literary processes of those years. Delayed classical bringing indicated the fact that the Albanian literature was inclined to try out any paths of evolvement, paths which would further develop and enrich it.

\section{The Place E. Haxhiademi Occupies in the Albanian Dramaturgy}

Just as in the classical dramaturgy, E. Haxhiademi's subjects try to balance;

1- Major interests of great characters, Kings and Queens, military commanders, princes and princesses, popular leaders whose actions have been promoted by the powerful passion of being omnipotent. This passion becomes the cause of their tragic failure. Characters like Zanfina, Hamza and, for a certain period of time, even Moses in Scanderbeg, Atal, in Alexander, act under the unaffordable power of this passion; their actions affect the destiny of states, kingdoms alongside involving other passions with it, such as love, revenge, (the love of Philip for Cleopatra in the tragedy Alexander, the love of Achilles for Polixeny - the King Priam's daughter, in Achilles, the King Priam's strong want to revenge to Achilles, the love of Olympiad for Philip and her hatred for Cleopatra, his second wife, etc, ). All these revelations contribute to the completion of the main 
action - the protection of the royal ruling and its inheritance1.

2- In compliance with the classical principles, those subjects intended to deal with the perpetual passions of the people, with their greed to rule and their love and vengeance leading them to their ultimate destruction. In cases their actions were considered to be fair, namely, led by reason, they incarnated the virtue, whereas on the contrary, they permeated vice. In-fighting between them was very fierce because vice made use of all the intrigues and wickedness's and would not stop even in the face of crime. In these terms, Olympiad, (Alexander), blind by her hatred to Philip, killed Cleopatra, her rival, who was pregnant, whereas King Priam took advantage of his daughter's feelings, Polyxeny, to do away with her lover, Achilles.

With some of his tragedies Haxhiademi wanted to realize:

a- The well-known classical principle according to which humans are neither quite prefect nor quite evil to exhaustion. After a mistake or a weakness they suffer heavy consequences that do not depend on them whereas most of them, he does not deserve. In the tragedy with the same name, Achilles becomes a victim of both King Priam's legitimate hatred and his predilection for Polyxeny - King Priam's daughter. The same occurs with Philip (in Alexander), who, with his mind lost because of his love for Cleopatra, falls prey of Gaelon's intrigues and was killed by Paussant. The same was Ulysses - the hero of tragedy bearing his name, killed by his son, Telagonus, the son who was born by his love with Circe $^{2}$.

b- The strength of their power and temptation thereof. Powerful passions thrived both in the temperament and conduct of those who could afford to bear, realize them or suffer from them, in the life of the mythical heroes as well as in the life of the high strata of the society. It was natural for the characters of classical tragedies to be taken from those strata of the society. Characters of Haxhiademi's tragedies are either heroes from the Greek mythology, (Achilles, Diogenes, Ulysses, etc) or Kings and Queens, leaders or their relatives, (Pyrrhus, Scanderbeg, Hamza, etc), representing great interests for the fates of their states.

c- In their literary work, all classics were moralists. They openly accepted this inclination and considered creations educating via grandeur to bear real values. E. Haxhiademi abided to this point of view, too, while not hesitating to ascertain, when directing to readers, that in one of his own literary works, the "Abel", he had written about a moral thesis. In general, in all his creativity, Haxhiademi had been trying to realize the wellknown principle of the classics; teaching and educating via favourite models deriving from the hymnization of the virtue in fight against vice.

d- The plots of Haxhiademi's literary works, in compliance with the classical spirit, try to be extraordinary, too radiant, away from the worries of everyday life which, for classics were not considered deign to be reflected in art.

e- By imitating classical tragedy on all its sides, Haxhiademi tries to reflect, in his work not only the feeling of the greed of the royal power but other feelings as well, such as the love, parental compassion and nobility, always under the subjection of reason - the only force protecting virtue and the right and leading to them ${ }^{3 "}$.

The classicism of Haxhiademi's tragedies has been noticed long ago; "Just as in the other tragedies of this author, remarked A Xhuvani - this tragedy, 'The Scanderbeg', has classical inspiration; it is divided in five acts, there are few characters and the weaving of the subject as a whole maintains the classical rules of the dramatic art. Mr. Etehem Haxhiademi - the classical admirer, loves to create tragedies instead of dramas" 4

\section{Can Etehem Haxhiademi be Considered a Neoclassic Writer?}

In order to get the response to this question we thought it over to present some opinions over neoclassicism, taken from Caroline Dauphin, La poésie neo-classique en France et en Angleterre, në Comparatisme en Sorbonne 4-2013: (De)construire le canon.

Neoclassicism should not be considered as an artistic tendency inculcated firmly into the history of literature; it is more an inclination of thinking with a certain stretching, a complex net of influences, a bridge connecting illuminist ideas with romantic ideals; a certain paradoxical equilibrium between tradition and modernity; a tendency for a new rapport

\footnotetext{
${ }^{1}$ Xhiku, Ali, The romanticization of the literary currents of realism, Tiranë, 1989.

2 Xhiku, Ali, The Albanian Literature as Polyphony, Tiranë, 2004, p. 277.

${ }^{3}$ Xhiku, Ali, The romanticization of the literary currents of realism, Tiranë, 1989, p. 153.

${ }^{4}$ Xhuvani, Aleksandër, A new Albanian tragedy - Illyria, Tiranë, nr. 37, 4 January 1936; no. 38, 11 January 1936, p. 3-4. 
between the neoclassic poetry and the solid canons/rules of classicism. In fact, neoclassicism is not simply a postclassicism, which would be a servile and humble imitation of the Elders; it is more an original and impressing treatment of ancient subjects and foregoing models. Behind the refusal to simply continue on the trails of the classical tradition should be seen the unproclaimed desire to re-establish classical canons and rules.

However, is it possible for a contradiction to exist between the proclaimed loyalty to an artistic and literary past and the assertion of its recreation, the search for the new and untested style in advance? The neoclassic concept per se is elusive, perceived as hanging between the past and the present, as the preceding model and the one following it, what is be quested and what is distorted.

At least, the creation of this "classical » canon would kindly be accepted to fill a gap in the national literary culture by selecting from an elitary culture. On the other side, these intentions reveal political tendencies. In figurative and plastical arts, neoclassicism has actually arts served to the Revolution and the Empire; the presentation of the figure of Napoleon as a New Caesar by Jacque-Louis David has always been considered as a pretty illustrative example. Neoclassic poetry served to this very aim, too, it reconstructed the canon and made possible a new social, cultural and ideological model.

Neoclassicism in literature, (despite its greatest development in figurative, plastical arts and architecture), was spread to different countries of Europe, especially in France and England. Both currents, in France and England had common sources in terms of the influence of the Great Century, the illuminists' ideas as well as the ancient models. Both of them require perfection of humans through their deeds described by poetry, the formal rules of symmetry and the harmony of dimensions; etymology of canon is re-found to derive from Greek word kanôn, which in its origin shows a measurement tool. On the other side, the great political and commercial rivalries between France and England could not hamper writers from both sides to have an ongoing adoration for classical models. Pope adores Boileau's genius and it seems to make his dream of Boileau's « Poetical Art » come true by writing «Essay on Criticism»: on the other side, Delille translated Milton in French.

The fundamental distinction between the English and French neoclassicism is undoubtedly, their time of radiance ; in France the poetical neoclassicism was developed in a short but intensive period, by $1780-1820$, dominated by Jacques Delille, André Chénier, and/or Jacque Clinchamps de Malfilâtre. In England the movement renovated French classics, being mainly inspired by Boileau. Milton, Dryden and later on Pope are salient and re-establish the classical rules of poetry by renovating, mainly, the art of satire.

Neoclassicism would be a modern term for writers evoking values of the Elders. Their legacy would disguise, in fact, a debatable rebuilt of the canon, somewhere between continuity and re-creation, in order to shape a national literature, serving to various political ambitions, as well.

Neoclassic poetry proposes an original re-reading of the classical models, be ancient authors or writers of the Great Century. In this framework, the translation of great poems of antiquity takes special interest. «By means of translation beyond linguistic transcription, the original the translator(s) consideration propose a new perspective and presents texts from a new point of view. Translation is, first of all, re-interpretation and re-actualization; it is product of a confidential dialogue permeating words and centuries in order to thoroughly recover the source text ».5

Even though they adore Elders/Ancients, they still are closer to Modern creators; they want to emulate with their models by creating a thoroughly original work. Dryden expresses this aim openly when he started to translate Virgil, Anaidea, and the Bucoliques.

New translations make possible for the Antiquity to be discovered under a new point of view, alongside archaeological discoveries of the time from the ruins of Pompey. Dryden in England shows to be classical by his reference and neoclassic by his ambitions, fed by a style as sensitive as it was elegant.

The illuminists' influence to neoclassics evolves a different attitude to them regarding the Elders and the classics per se; so they are admirers of the Ancients, they appear as humans of their own time, eager for knowledge and great scientific curiosity.

For the classics the ancient references were re-devised by creating new relationships of the contemporary figures with ancient heroes. The poetry, too, retakes a political inclination. The classical canon is clearly used as a powerful ideological vector, destined to dramatize revolutionary episodes. By connecting present with the past Camille Desmoulins and André Chénier tended to convey revolution a timeless and universal character, in order for them to be the Horaces and Ovides of the time they lived in. 
Therefore, neoclassicism is not a simple gathering of re-writings and translations from Virgil and illuminists; it is firstly an art in response to a historical need and in special political and cultural circumstances. The same way is it a supportive art for the future generations, a resource for pre-romantics, although some modernists, like Baudelaire, consider it solely a literary shade comparable to a cloud of grasshoppers.

Neoclassicism is neither post-classicism as well, since it would loyally follow the entire predecessors of antiquity. However, it is neoclassicism which recovered classical canons in order to adapt it to a new esthetical and political ideal. Far from being the twilight of classicism, it is the new dawn of an early morning ${ }^{6}$.

\section{Conclusions}

By making clear what neoclassicism is, we can squarely consider Haxhiademi's work, in which there are more concomitances of ideas and esthetical and practical ideals which conceived neo-classicist experiences in Europe. These concomitances are clearly distinguishable in Haxhiademi's literary practices;

- At the beginnings of his literary works Haxhiademi translated Virgil's Bucoliques so conveying a clear testimony for the inclinations of an art that could be re-read and re-written.

- He committed himself to poetry as well, alongside dramaturgy and translations.

- In his experiences of poetical creativity we find concomitances with the neoclassics' ideas and intentions.

- A different point of view from the classics' experiences was noticed in his dramaturgy, in terms of perceiving and treating characters and heroes as well as in conceiving and transmitting ideas.

This does not mean he was a representative of neoclassicism since in the Albanian context as well as for the certain level of social, political, cultural and ideological developments, moreover, for the coeval level of the evolvement of dramaturgy, it was impossible to follow and create neo-clasicist models of the literary and artistic works, (such a big leap could never even be made by a young playwright, howsoever cultivated and talented he was, because, so far there were no previous models of classicism conveyed to the literary experience of the Albanian literature); it was cosier and more suitable and functional in those conditions for other ideas or different intentions to be conceived, even similar to neoclassic nature, not necessarily intending the recreation of canons and new rules but aiming integration to the classical canons; and that is what Haxhiademi did, thus making recognition and inclination of this testimony be obvious even for neoclassicism.

By considering the nature of Haxhiademi's work from this point of view, the reason why in the 20th century an author like him considered literary a model of 3-4 centuries ago and not a later any models such as neoclassicism, is naturally explicated, particularly by a writer who was grown up and cultivated in European civilized ambiances.

Precisely this declamation of syncretism of both the classical and neoclassic elements became the cause for commencing debates, approvals and disapprovals in 1930s and 1940s - a debate that, in a certain way, goes on even today.

\section{References}

"Ulysses", Berlin 1924, published in Tirane, Albania in 1931.

"Achilles", Viena1926, published in Tirane, Albania in in 1931.

"Alexander", Lushnje 1928, published in Tirane, Albania in 1931.

"Pyrrhus", Gjirokastër 1934, published in Tirane, Albania in 1934.

"Scanderbeg", published in Tirana, Albania in 1935.

"Diomedes", Gjirokaster 1936, published in Tirane, Albania in 1936.

"Abel", published in Elbasan, Albania in 1938.

The book of poetry "Lyra ", published in Elbasan, Albania in 1939.

Dauphin, Caroline, La poésie neo-classique en France et en Angleterre, (De)construire le canon, in Comparatisme en Sorbonne 42013.

Lianeri, Alexandra; Zajko, Vanda: Classical Presences, Identity as Change in the History of Culture, University Press, Oxford, 2008.

Xhiku, Ali, The Albanian Literature as Polyphony, Tirane, 2004, p. 277.

Xhiku, Ali, The romanticization of the literary currents of realism, Tiranë, 1989. p. 153.

Xhuvani, Aleksandër, A new Albanian tragedy - Illyria, Tirane, nr. 37, 4 January 1936; no. 38, 11 January 1936, p. 3-4.

${ }^{6}$ Dauphin, Caroline, La poésie neo-classique en France et en Angleterre, (De)construire le canon, në Comparatisme en Sorbonne 42013. 